\title{
Metode Perubahan Undang-Undang Dasar 1945 dan Perbandingannya dengan Konstitusi di Beberapa Negara
}

\author{
Taufiqurrohman Syahuri \\ Fakultas Hukum Universitas Bengkulu \\ J1. Raya Kandang Limo Bengkulu \\ tsyahuri@gmail.com
}

\begin{abstract}
The process of amending UUD 1945 has created different kinds of views regarding its form of amendment. One side demands "amendment system" as the one applied in United State of America. The other side demands a total change by creating a new constitution such as in France, Netherlands, and Germany. The main problem that would be investigated and answered in this research is how the amendment of constitution in theory and constitutions in several countries. This research is a case study about the method used in the amendment of constitution. The approach used in this research is not only normative jurisdiction, but also comparative approach, because it has normative comparison on the constitutions in several countries. This research has concluded; first, the way UUD 1945 amended theoretically does not divert from the general principles of constitution changing and democracy country. Second, the amendment of UUD 1945 follows the form of the amendment or constitutional adandum of United States of America.
\end{abstract}

Key words : Constitution, amendment, UUD 1945

\begin{abstract}
Abstrak
Proses perubahan UUD 1945 memunculkan beragam pandangan mengenai bentuk perubahannya. Satu sisi menghendaki "sistem amandemen" seperti yang dipraktekkan di negara Amerika Serikat, sedang sisi yang lain menghendaki perubahan secara total dengan cara membentuk undang undang dasar baru seperti di Perancis, Belanda, dan Jerman.Masalah utama yang akan diteliti dan dijawab dalam penelitian ini adalah bagaimana cara perubahan konstitusi dalam teori dan konstitusi di beberapa negara. Penelitian ini merupakan penelitian kasus sekitar metode atau cara yang digunakan dalam perubahan konstitusi, karena itu pendekatan yang digunakan selain pendekatan yuridis normatif dan juga pendekatan komparatif karena melakukan perbandingan secara normatif terhadap konstitusi di berbagai negara. Penelitian ini menyimpulkan, pertama, cara perubahan UUD 1945 secara teori tidak mengimpang dari prinsip-prinsip umum perubahan konstitusi dan negara demokrasi. Kedua, perubahan UUD 1945 mengikuti bentuk amandemen atau adandum konstitusi Amerika Serikat.
\end{abstract}

Kata kunci : Konstitusi, amandemen, UUD 1945 


\section{Pendahuluan}

Undang-Undang Dasar Negara Republik Indonesia Tahun 1945 adalah nama resmi UUD 1945 yang telah diamandemen pada tahun 1999-2002. Walaupun UUD ini belum berapa lama diamandemen, tetapi ini pada tahun 2007, suara untuk melakukan perubahan atas UUD 1945 mulai mengemuka, dipelopori oleh beberapa anggota Dewan Perwakilan Daerah (DPD) yang menuntut penambahan kewenangan agar DPD memiliki otoritas dalam memutus pembentukan undang-undang. Suara yang diusung oleh DPD inipun akhirnya kandas karena tidak mendapat dukungan 1/3 anggota Majelis Permusyawaratan Rakyat (MPR) sebagai syarat pintu masuk perubahan UUD. Untuk mengetahui bagaimana sebuah UUD dapat dilakukan perubahan, perlu melihat cara-cara perubahan yang dilakukan oleh beberapa negara sebagai bahan perbandingan apabila kelak MPR menyetujui adanya perubahan UUD.

Secara historis, perubahan Undang-Undang Dasar Negara Republik Indonesia Tahun 1945 (selanjutnya ditulis UUD 1945) sebenarnya telah dilakukan sejak 2 bulan setelah UUD itu sendiri disahkan oleh PPKI pada 18 Agustus 1945. Melalui Maklumat Wakil Presiden Nomor X, Pasal IV Aturan Peralihan diubah, yang intinya menyebutkan bahwa semula Komite National merupakan pembantu Presiden dalam menjalankan segala kekuasaan sebelum MPR, DPR dan Dewan Pertimbangan Agung (DPA) terbentuk, kemudian diganti oleh Maklumat Wakil Presiden itu menjadi suatu lembaga yang berfungsi sebagai parlemen. Perubahan ini tidak mengubah teks UUD 1945 dan juga dilakukan tidak melalui prosedur Pasal 37. Perubahan UUD yang dilakukan melalui prosedur Pasal 37 baru dilakukan pada 1999 ketika setahun setelah Presiden Soeharto mengundurkan diri.

Pengunduran diri ${ }^{1}$ Soeharto sebagai Presiden Negara RI pada 21 Mei 1998, ${ }^{2}$ ternyata diikuti pula oleh runtuhnya sebuah mitos atau suatu pandangan yang sengaja dibangun oleh Presiden Soeharto pada waktu itu bahwa UUD 1945 bernilai "keramat". ${ }^{3}$ Berbagai seminar yang membicarakan masalah amandemen UUD 1945 digelar. Pada waktu itu gagasan yang dominan adalah pembatasan kekuasaan dan

${ }^{1}$ Setelah berkuasa sejak 1967, Presiden Soeharto akhirnya pada 21 Mei 1998, pukul 09.00, menyatakan berhenti dari jabatan presiden setelah terjadi gelombang unjuk rasa besar-besar yang dimotori oleh kalangan mahasiswa, pemuda dan berbagai komponen bangsa di Jakarta dan juga di seluruh daerah. Saat itu juga BJ Habibie, wakil presiden lama, mengucapkan sumpahnya sebagai Presiden RI yang baru.

${ }^{2}$ Willem Oltmans, Chaos in Indonesia, terjemahan Wahjoedi Marjono, Surya Multi Grafika, Cet. 1, Jakarta, 2001, hlm. 7.

${ }^{3}$ Yusril Ihza Mahendra, Dinamika Tata Negara Indonesia, Gema Insani Press, Jakarta 1996, hlm. 12-13. 
masa jabatan presiden. ${ }^{4}$ Hal ini dapat dipahami karena masyarakat melihat pengalaman pemerintahan masa lalu yang lebih didominasi oleh kekuasaan presiden. Selain itu, banyak hal yang dicantumkan didalamnya seringkali memiliki makna ganda. ${ }^{5}$ Keadaan inilah yang kemudian oleh penguasa dijadikan dasar dalam menafsiran pasal-pasalnya sesuai dengan kepentingan politiknya.

Proses perubahan UUD 1945 muncul beragam pandangan mengenai bentuk perubahannya. Satu sisi menghendaki "sistem amandemen" seperti yang dipraktikkan di negara Amerika Serikat, ${ }^{6}$ sedang sisi yang lain menghendaki perubahan secara total dengan cara membentuk undang undang dasar baru seperti di Perancis, Belanda, dan Jerman. ${ }^{7}$ Demikian juga dalam tata cara perubahannya, sebagian berpandangan menginginkan disahkan melalui referendum dan sebagian lain menghendaki dibentuk komisi konstitusi yang bertugas merumuskan rancangan undang-undang dasar secara utuh. Sungguhpun demikian, berbagai pandangan tersebut ternyata sama-sama tidak mempersoalkan Pembukaan UUD 1945. Akhirnya, MPR hasil pemilihan umum demokratis tahun 1999, dalam Sidang Umumnya berhasil mengubah UUD 1945 untuk yang pertama kalinya. ${ }^{8}$ Perubahan tersebut dilakukan berdasarkan Pasal 37 dengan sistem amandemen seperti yang dilakukan oleh Amerika Serikat.

\section{Rumusan Masalah}

Berdasarkan uraian latar belakang di atas maka masalah utama yang akan diteliti dan dijawab dalam penelitian ini adalah bagaimana cara perubahan konstitusi dalam teori dan dalam konstitusi serta pelaksanaannya di Indonesia serta di beberapa negara?

${ }^{4}$ Sebagai contoh, Maswadi Rauf, guru besar ilmu politik, dalam sebuah Seminar di Jakarta menyarankan agar Pasal 7 tentang pembatasan masa jabatan presiden direvisi. Pendapat yang sama juga disampaikan oleh Mochtar Probotinggi; Kompas, 15 Juni 1999, hlm. 1.

${ }^{5}$ Ismail Suny, Pergeseran Kekuasaan Eksekutif, CV Calindra, Cet.2, Jakarta 1965, hlm.3.

${ }^{6}$ Lihat: Richard B. Bernstein, With Jerome Agel, Amending America, Times Books Random House, First Edition, New York, 1993, hlm. xii; 301-307.

${ }^{7}$ CF Strong, Modern Political Constitutions, Sedgwick \& Jackson, London, 1973, hlm. 160.

${ }^{8}$ Sesuai dengan tuntutan masyarakat pada waktu itu, Perubahan Pertama UUD 1945 telah membatasai masa jabatan dan kekuasaan presiden sebagaimana tersebut dalam Pasal 7 dan Pasal 20. 


\section{Tujuan Penelitian}

Penelitian ini bertujuan untuk menganalisis cara perubahan konstitusi dalam teori dan konstitusi serta pelaksanaannya di Indonesia dan praktiknya di beberapa negara.

\section{Metode Penelitian}

Penelitian ini merupakan penelitian hukum normatif, yaitu penelitian tentang norma-norma hukum dan pengertian hukum atau dogmatik hukum. ${ }^{9}$ Sebenarnya penelitian mengenai prosedur perubahan UUD 1945 yang dilakukan oleh penulis ini merupakan penelitian yang kedua setelah penelitian yang dilakukan oleh Sri Soemantri pada tahun 1978 dengan judul "Persepsi Terhadap Prosedur dan Sistem Perubahan Konstitusi Dalam Batang Tubuh Undang Undang Dasar 1945"..$^{10}$ Jika Sri Soemantri mengkajinya dari segi persepsi tentang prosedur perubahan secara normatif semata dengan perbandingan tiga negara, maka penulis mengkaji penelitian ini, selain dari segi normatif, juga dari segi implementasi atas perubahan pertama, kedua, ketiga dan keempat UUD 1945 dengan perbandingan seratus negara secara kuantitatif non statistik yakni dengan menggunakan tabel. Kebetulan saat dilakukan penelitian ini sedang berlangsung proses perubahan UUD 1945. Dalam hal ini yang diteliti adalah cara perubahan pertama sampai dengan keempat UUD 1945 yang telah dilakukan oleh MPR pada 1999 sampai dengan 2002. Sebagai bahan analis dibahas juga sejarah perubahan konstitusi di Indonesia, serta prinsip-prinsip perubahan konstitusi pada umumnya.

Penelitian ini juga merupakan penelitian kasus (studi kasus) sekitar metode atau cara yang digunakan dalam perubahan konstitusi, dan latar belakangnya. Karena itu pendekatan yang digunakan selain pendekatan yuridis normatif juga dilakukan pendekatan socio legal. Penelitian ini juga bersifat komparatif karena melakukan perbandingan secara normatif untuk ditemukan persamaan dan perbedaanya dimana mungkin dibuat perbandingan. Data pembanding ini adalah teori konstitusi, dan cara perubahan konstitusi di berbagai negara.

\footnotetext{
${ }^{9}$ Soerjono Soekanto dan Sri Mamudji, Penelitian Hukum Normatif, In-Hilco, Jakarta 1990, hlm. 14.

${ }^{10}$ Sri Soemantri, Prosedur dan Sistem Perubahan Konstitusi, cetakan pertama, Alumni, Bandung, 1978.
} 
Sumber data utama penelitian diperoleh melalui studi kepustakaan yang berupa data sekunder. Data sekunder ini terdiri dari : (1) bahan hukum primer, yaitu UUD 1945 dan Perubahannya, Konstitusi RIS, UUD Sementara tahun 1950, Konstitusi negara lain serta beberapa peraturan perundang-undangan terkait; (2) bahan hukum sekunder yang tertulis di buku-buku, hasil penelitian, risalah sidang, dan artikel atau tulisan-tulisan ilmiah lainnya; dan (3) bahan hukum tertier berupa kamus hukum, kamus umum dan ensiklopedi. ${ }^{11}$ Data ini akan dilengkapi dengan pandangan atau pemikiran yang berkembang dalam masyarakat yang melatar-belakangi lahirnya Perubahan UUD 1945 yang tersebar dalam kliping atau media lain. Selain itu, juga dilakukan observasi dengan mengikuti secara langsung atau menyaksikan melalui media televisi tentang proses perubahan Undang-Undang Dasar 1945 di lembaga MPR. Cara ini dilakukan karena kebetulan penelitian ini dilaksanakan ketika proses perubahan undang undang dasar itu sedang dibahas oleh MPR. Analisis data akan dilakukan secara kualitatif dengan pendekatan diskriptif-analitis dan mengacu pada kerangka pemikiran teori di atas.

\section{Hasil dan Pembahasan}

Secara khusus peneliti akan memusatkan analisisnya pada sejarah perubahan konstitusi di Indonesia. Analisis sejarah perubahan konstitusi ini merupakan informasi awal yang diperlukan guna diketahui identitas perubahan konstitusi tersebut. Kajian ini didasarkan pada urutan kejadian, dimulai sejak perubahan naskah "Hukum Dasar" hasil karya Dokuritsu Zyunbi Tyoosakai menjadi Undang-Undang Dasar Proklamasi (1945), kemudian diganti dengan Konstitusi Sementara Republik Indonesia Serikat (1949), dan UUDS (1950), sampai dengan kembali lagi ke UUD 1945 melalui Dekrit Presiden 5 Juli 1959.

Berbicara mengenai sejarah perubahan konstitusi di Indonesia, rasanya kurang lengkap apabila tidak dimulai dari "Hukum Dasar"12 hasil karya Dokuritsu Zyunbi Tyoosakai (Badan Penyelidik Usaha-usaha Persiapan Kemerdekaan Indonesia Badan Penyelidik Usaha-usaha Persiapan Kemerdekaan Indonesia)pada masa pendudukan

${ }^{11}$ Ibid.

${ }^{12}$ Hukum Dasar ini adalah istilah resmi yang dipakai oleh BPUPKI untuk menyebut undang undang dasar yang dibuatnya. Hukum Dasar ini bukan rancangan tetapi undang undang dasar (tetap) yang dibuat oleh Dokuritsu Zyunbi Tyoosakai. Baca, Harun Alrasid, 'Ketetapan MPR Suatu Pemikiran Kembali”, dalam Pekan Ilmiah, Lembaga Penelitian Hukum Fakultas Hukum Universitas Sriwijaya, Palembang, 1976, hlm. 48. 
Balatentara Jepang. Hukum dasar itu kemudian berubah menjadi Undang-Undang Dasar Negara Republik Indonesia setelah ditetapkan oleh Panitia Persiapan Kemerdekaan Indonesia pada 18 Agustus 1945, yang kemudian lebih dikenal dengan isitilah “Undang-Undang Dasar 1945”.

Undang-Undang Dasar 1945 pertama kali ditetapkan dan disahkan oleh Panitia Persiapan Kemerdekaan Indonesia (PPKI). Walupun pada awalnya PPKI dibentuk oleh Pemerintah Balatentara Jepang dengan nama "Dokuritsu Zyunbi Inkai", namun ketika melakukan pengesahan Undang-Undang Dasar itu, ia bertindak bukan lagi atas nama Pemerintah Balatenra Jepang melainkan bertindak atas nama bangsa Indonesia sendiri, karena sejak Tentara Jepang menyerah kepada Sekutu, Pemerintah Jepang tidak punya kewenangan lagi mengontrol kegiatan Panitia Persiapan Kemerdekaan Indonesia. ${ }^{13}$ Kronologis hilangnya kewenangan Pemerintah Balatentara Jepang atas PPKI dapat dilihat pada penuturan saksi sejarah Bung Hatta sebagai berikut: ${ }^{14}$ "Kesaksian sejarah Bung Hatta tersebut secara normatif dapat diartikan bahwa Pemerintah Balatentara Jepang tidak lagi mempunyai legitimasi atas kekuasaan bangsa Indonesia, oleh karena itu segala akitivitas Panitia Persiapan Kemerdekaan Indonesia adalah bersifat independen bukan lagi di bawah kekuasaan Pemerintah Jepang melainkan atas nama bangsa Indonesia sendiri. Ini menunjukkan suatu bukti bahwa yang membentuk UUD $1945 \mathrm{itu}$ adalah bangsa Indonesia sendiri melalui lembaga PPKI. Dalam rapat PPKI naskah konstitusi Hukum Dasar hasil karya Dokuritu Zyunbai Tyoosakai (BPUPKI) diubah menjadi seperti yang sekarang tertulis dalam naskah asli UUD 1945".

Rancangan hukum dasar yang disusun oleh Panitia Perancang Hukum Dasar bentukan BPUPKI itu terdiri dari 42 pasal termasuk di dalamnya Pasal tentang Peralihan yang terdiri dari 5 pasal dan 1 pasal Aturan Tambahan. Dalam rancangan ini tidak ada pasal yang mengatur perubahan konstitusi, demikian juga setelah disahkan menjadi hukum dasar oleh BPUPKI tidak ada pasal perubhannya. Namun demikian bukan berarti masalah perubahan konstitusi itu tidak pernah dibicarakan. Dalam pembahasan rancangan undang undang dasar itu ada yang mempersoalkan

${ }^{13}$ A.G. Pringgodigdo, dalam ceramahnya di depan Pengurus Ikatan Sarjana Hukum Indonesia (ISHI) mengatakan: "Kemerdekaan dengan pernyataan oleh Jepang tidak mungkin karena Jepang terikat oleh janji yang diberikan pada waktu menyerah (kepada Sekutu-pen), untuk mempertahankan "status-quo" di semua daerah-daerah yang diduduki, artinya tidak akan mengadakan perubahan dalam status daerah-daerah itu sampai menyerahkan kekuasaannya kepada pasukan-pasukan sekutu; Sebagaimana dimuat dalam majalah Hukum dan Masyarakat, Tahun III No. 2 Mei 1958, hlm. 3-26.

${ }^{14}$ Mohammad Hatta, Memoir Mohammad Hatta, Tintamas, Jakarta 1982, hlm. 452-453. 
ketentuan perubahan undang-undang dasar. Sebagai contoh, usul dari anggota Kolopaking dalam rapat besar BPUPKI tanggal 11 Juli 1945, yang menyatakan sebagai berikut: ${ }^{15}$

"Seperti dalam pembicaraan saya kemarin, saya mengatakan bahwa semua susunan pada waktu ini amat dipengaruhi oleh suasana peperangan, maka saya usulkan kepada Panitia yang didirikan, supaya Undang-Undang Dasar itu disusun demikian, sehingga gampang diubah dan disesuaikan dengan keadaan jaman yang akan datang ... Maka di dalam Undang-Undang Dasar itu, menurut pemandangan saya, harus ada satu pasal yang menggampangkan Undang-Undang Dasar itu secepat mungkin disesuaikan dengan permintaan dan keadaan zaman yang akan datang itu. Barangkali tidak usah hal itu saya terangkan dengan panjang lebar".

Rancangan hukum dasar hasil kerja panitia perancang hukum dasar itu, setelah diadakan perubahan di sana sini atas usul anggota rapat Badan Penyelidik ini, pada akhirnya ditetapkan menjadi hukum dasar dengan jumlah pasal menjadi 36 Pasal $^{16}$ tidak termasuk Aturan Tambahan dan Aturan Peralihan. Perubahan tersebut mencakup perubahan redaksi bagian Pembukaan, dan Pasal-pasal termasuk ketentuan Peralihan dan Aturan Tambahannya.

Hukum dasar hasil karya BPUPKI itu oleh Sidang PPKI 18 Agustus 1945 dijadikan sebagai naskah Rancangan Undang-Undang Dasar Negara Republik Indonesia. Setelah mengalami pembahasan dalam waktu yang sangat singkat kurang lebih dua jam, hukum dasar tersebut disahkan menjadi Undang-Undang Dasar Negara Republik Indonesia dengan perubahan yang sangat mendasar. ${ }^{17}$ Gambaran perubahan tersebut adalah sebagai berikut:

\footnotetext{
${ }^{15}$ Sekretariat Negara Republik Indoenesia, Risalab Sidang Badan Penyelidik Usaha Usaha Persiapan Kemerdekaan Indonesia, Panitia Persiapan Kemerdekaan Indonesia, 28 Mei 1945 - 22 Agustus 1945, Sekneg RI, Jakarta 1995, cet. 1 edisi III, hlm. 166.

${ }^{16}$ Muhammad Yamin, Naskah Persiapan UUD 1945, Jilid I, Prapantja, Jakarta, hlm. 396.

${ }^{17}$ Perubahan yang mendasar ini terkait dengan anak kalaimat atau kata-kata yang menyebut istilah "Islam". Penerimaan perubahan tersebut oleh kalangan politik Islam (Masyumi), didasari atas pertimbangan pargmatis. Sikap pragmatis ini didasarkan kepada konsensus bersama bahwa UUD yang ditetapkan pada 18 Agustus 1945 oleh PPKI masih bersifat "sementara". Karena itu, Kalangan politik Islam berharap “isi dan sifat Islam” dapat diperjuangkan nanti pada saat negara akan menyusun UUD tetap. Baca: Yusril Ihza Mahendra, Modernisme dan Fundamentalisme dalam Politik Islam, Paramadina, Jakarta, 1999, hlm. 74.
} 
Tabel 1

Perbedaan Hukum Dasar BPUPKI dan UUD PPKI (Proklamasi) ${ }^{18}$

\begin{tabular}{|c|c|c|}
\hline No & Hukum Dasar (BPUPKI) 16-7-1945 & Undang Undang Dasar (PPKI) 18-8-1945 \\
\hline 1. & Istilah "Hukum Dasar" & Diganti menjadi “Undang-Undang Dasar". ${ }^{19}$ \\
\hline 2. & Mukadimah & Diganti dengan: Pembukaan \\
\hline 3. & $\begin{array}{l}\text { Kalimat Pembukaan alinea ketiga: "Atas } \\
\text { berkat Rakhmat Allah Yang Maha Kuasa.." }\end{array}$ & $\begin{array}{l}\text { Diganti menjadi: "Atas berkat Rakhmat Tuhan } \\
\text { Yang Maha Esa.. ." }\end{array}$ \\
\hline 4. & $\begin{array}{l}\text {...dalam suatu Hukum Dasar Negara } \\
\text { Indonesia... }\end{array}$ & $\begin{array}{l}\text { Diubah dengan: ...dalam suatu Undang- } \\
\text { Undang Dasar Indoesia... }\end{array}$ \\
\hline 5. & $\begin{array}{l}\text {...Dengan berdasarkan kepada ke-Tuhanan } \\
\text { dengan kewajiban menjalankan syariat Islam } \\
\text { bagi pemeluk-pemeluknya... }\end{array}$ & $\begin{array}{l}\text { Diubah menjadi: ...dengan berdasarkan } \\
\text { kepada ke-Tuhanan Yang Maha Esa.. }\end{array}$ \\
\hline 6. & $\begin{array}{l}\text {...menurut dasar kemanusiaan yang adil dan } \\
\text { beradab. }\end{array}$ & $\begin{array}{l}\text { Diganti dengan: Kemanusiaan yang adil dan } \\
\text { beradab. }\end{array}$ \\
\hline 7. & Dua orang wakil presiden & Diganti menjadi: seorang wakil presiden \\
\hline 8. & $\begin{array}{l}\text { Presiden haruslah orang Indonesia asli yang } \\
\text { beragama Islam }\end{array}$ & $\begin{array}{l}\text { Diganti menjadi: Presiden harus orang } \\
\text { Indnesia asli.. }{ }^{21}\end{array}$ \\
\hline 9. & $\begin{array}{l}\text { Presiden Indonesia memegang kekuaaan } \\
\text { pemerintahan }\end{array}$ & $\begin{array}{l}\text { Presiden Indonesia memegang kekuasaan } \\
\text { pemerintahan menurut Undang-Undang } \\
\text { Dasar. }\end{array}$ \\
\hline 10. & $\begin{array}{l}\text { Negara berdasar atas ketuhanan dengan } \\
\text { kewajiban menjalankan syariat Islam bagi } \\
\text { pemeluk-pemeluknya. }\end{array}$ & $\begin{array}{l}\text { Negara berdasar atas Ketuahan Yang Maha } \\
\text { Esa. }\end{array}$ \\
\hline 11. & $\begin{array}{l}\text { Syarat-syarat untuk menjadi hakim } \\
\text { ditetapkan oleh undang-undang }\end{array}$ & $\begin{array}{l}\text { Syarat-syarat untuk menjadi dan diberhentikan } \\
\text { sebagai hakim ditetapkan oleh undang-undang }\end{array}$ \\
\hline 12 & Tidak ada ketentuan Perubahan UUD & $\begin{array}{l}\text { Diatur ketentuan perubahan undang undang } \\
\text { dasar. }\end{array}$ \\
\hline 13. & $\begin{array}{l}\text { Dalam melaksanakan pertahanan dan } \\
\text { pembelaan negara dalam peperangan Asia } \\
\text { Timur Raya ini, Negara Indonesia bekerja } \\
\text { bersama seerat-eratnya dengan Dai Nippon. }\end{array}$ & Dihapus. \\
\hline 14. & $\begin{array}{l}\text { Jumlah pasal } 42 \text { (termasuk Ketentuan } \\
\text { Peralihan dan Aturan Tambahan) }\end{array}$ & $\begin{array}{l}\text { Jumlah pasal } 37 \text { plus } 4 \text { pasal Aturan Peralihan } \\
\text { dan } 2 \text { ayat Aturan Tambahan. }{ }^{22}\end{array}$ \\
\hline
\end{tabular}

${ }^{18}$ Data diambil dan diolah dari buku Risalah BPUPKI dan PPKI 28 Mei - 22 Agustus 1945, Sekretariat Negara, Jakarta, 1995, dan Muhammad Yamin, Naskah ...Loc., Cit.

${ }^{19}$ Perubahan istilah ini atas usul Soepomo, karena istilah hukum dalam Hukum Dasar itu meliputi hukum tertulis dan tidak tertulis, sedangkan undang-undang adalah hukum yang tertulis saja. Ismaun, Pancasila Dasar Filsafat Negara Republik Indonesia, Carya Remaja, edisi IV, Bandung, 1977, hlm. 186-193.

${ }^{20}$ Lihat Muhammad Yamin, Naskah ... Op., Cit, hlm. 406. Kalimat ini kemudian dikembalikan menjadi "Atas berkat rakhmat Allah Yang Maha Kuasa.. ." dalam UUD 1945 Dekrit Presiden 5 Juli 1959.

${ }^{21}$ Ketentuan ini telah diubah lagi dalam amandemen ketiga sehingga berbunyi sebagai berikut: "Calon Presiden dan calon Wakil Presiden harus seorang warga negara Indonesia sejak kelahirannya dan tidak pernah menerima kewarganegaraan lain karena kehendaknya sendiri, tidak pernah mengkhianati negara, serta mampu secara rohani dan jasmani untuk melaksanakan tugas dan kewajiban sebagai Presiden dan Wakil Presiden (Pasal 6 Ayat (1) UUD 1945 Perubahan Ketiga)

${ }^{22}$ Setelah amandemen keempat tahun 2002 terjadi perubahan jumlah pasal pada Aturan Perlihan menjadi 3 pasal, dan Aturan Tambahan berjumlah 2 pasal. 
Undang-Undang Dasar yang disahkan oleh PPKI itu dengan perubahanperubahan seperti di atas, kemudian diumumkan dengan resmi dalam Berita Republik Indonesia Tahun II No. 7 tanggal 15 Pebuari 1946.

\section{Pengertian Konstitusi}

Konstitusi merupakan sesuatu yang sangat penting bagi setiap bangsa dan negara, baik yang sudah lama merdeka maupun yang baru saja memperoleh kemerdekaannya. Dalam buku "Corpus Juris Scundum" volume 16, pengertian konstitusi dirumuskan sebagai berikut: ${ }^{23}$ "A constitution is the original law bay which a system of government is created and set up, and to which the branches of government must look for all their power and authority".

Konstitusi juga dapat diartikan: "A constitution as a form of social contract joining the citizens of the state and defining the state itself". ${ }^{24}$ Konstitusi memiliki fungsi-fungsi antara lain fungsi pembatan kekuasaan organ negara dan simbolik pemersatu (symbol of unity). Dalam praktik, istilah konstitusi sering digunakan dalam beberapa pengertian. Di Indonesia selain dikenal istilah konstitusi juga dikenal istilah undangundang dasar. Demikian juga di Belanda, di samping dikenal istilah groundwetv (undang-undang dasar) dikenal pula istilah constitutie.

Sementara K.C. Wheare F.B.A dalam buku Modern Constitution, ${ }^{25}$ menjelaskan istilah konstitusi, secara garis besarnya dapat dibedakan ke dalam dua pengertian, yaitu: Pertama, istilah konstitusi dipergunakan untuk menunjuk kepada seluruh rules mengenai sistem ketatanegaraan. Kedua, istilah konstitusi menunjuk kepada suatu dokumen atau beberapa dokumen yang memuat aturan-aturan dan ketentuan-ketentuan tertentu yang bersifat pokok atau dasar saja mengenai ketetanegaraan suatu negara.

Berdasarkan uraian di atas, dapat ditarik suatu pemahaman bahwa pengertian konstitusi dan undang undang dasar menunjuk kepada pengertian hukum dasar suatu negara, yang mengatur susunan organisasi pemerintahan, ${ }^{26}$ menetapkan badan-

\footnotetext{
hlm. 21.

${ }^{23}$ Corpus Juris Scundum, Constitutional Law, Volume 16, Brooklyn, N.Y. The American Law Book, tanpa tahun,

${ }^{24}$ Dennis C.Mueller, Constitutional Democracy, Oxford University Press, 1996, hal. 61. Dalam buku ini juga, Dennis menyatakan: "A contract is an agreement among two or more individuals specifying certain duties, obligation, and rights of each individual, and penalties for complying or violating the terms of the contract”. Baca juga, Jean-Jacques Rousseau, The Social Contrat and Discourses. Terjemahan dalam bahasa Inggris oleh G.D.H. Cole, J.M.Dent \& Sons Ltd, Reprinted, London, 1991, hlm. 193 dst.

${ }^{25}$ K.C. Wheare F.B.A, Modern Constitution, Oxford University Press, London 1975, hlm. 1-2.

${ }^{26}$ Ibid., hlm. 14
} 
badan negara dan cara kerja badan tersebut, ${ }^{27}$ menetapkan hubungan antara pemerintah dan warga negara, ${ }^{28}$ serta mengawasi pelaksanaan pemerintahan. ${ }^{29}$ Perbedaannya hanya terletak pada proses terjadinya konstitusi itu. ${ }^{30}$ Di Indonesia sendiri pernah memakai kedua istilah tersebut, yaitu istilah "undang-undang dasar" dan istilah “Konstitusi RIS” (Konsitusi Republik Indonesia Serikat).

\section{Metode Perubahan Konstitusi}

George Jellinek membedakan dua jalur perubahan konstitusi, yaitu melalui cara: Pertama, yang disebut verfassungs-anderung, yakni cara perubahan konstitusi yang dilakukan dengan sengaja dengan cara yang ditentukan dalam konstitusi. ${ }^{31}$ Kedua, melalui prosedur yang disebut verfassungs-wandelung yakni perubahan konstitusi yang dilakukan tidak berdasarkan cara formal yang ditentukan dalam konstitusi sendiri, melainkan melalui jalur istimewa seperti, revolusi, kudeta (coup d'etat), dan konvensi. ${ }^{32}$

Sementara sistem yang dianut oleh negara-negara dalam mengubah konstitusinya dapat digolongkan ke dalam dua sistem perubahan. Pertama, apabila suatu konstitusi diubah maka yang akan berlaku adalah konstitusi yang baru secara keseluruhan, sehingga tidak ada kaitannya lagi dengan konstitusi lama. Sistem ini masuk ke dalam kategori constitutional reform (pembaruan konstitusi). Sistem ini dianut oleh hampir semua negara di dunia, di antaranya adalah Belanda, Jerman, dan Perancis. ${ }^{33}$

Kedua, sistem perubahan konstitusi, dimana konstitusi yang asli tetap berlaku, sementara bagian perubahan atas konstitusi tersebut merupakan adendum atau sisipan dari konstitusi asli tadi. Dengan kata lain, bagian yang diamandemen merupakan atau menjadi bagian dari konstitusinya. Jadi antara bagian perubahan dan bagian konstitusi aslinya masih terkait. Keberlakuan konstitusi dengan sistem perubahan inipun masih didasarkan kepada saat berlakunya konstitusi yang lama, sehingga nilai-nilai lama dalam konstitusi asli yang belum diubah masih tetap eksis. Sistem perubahan ini dianut oleh

\footnotetext{
${ }^{27}$ James Bryce, dalam C.F. Strong, Op. Ci.t, hlm. 11.

${ }^{28}$ Ivor Jenning, The Laws and the Constitution, University of London, 1960, hlm. 33.

${ }^{29}$ Russell F. Moore, Basic Comparative Government and Modern Constitution, Iowa, 1957, hlm. 3.

${ }^{30} \mathrm{Di}$ lihat dari prosedur terjadinya undang-undang, istilah konstitusi dapat dibedakan menjadi: (1) constitutie in materiele zin; (2) constitutie in formele zin; dan (3) grondwet. Lihat: Djokosutono, Hukum Tata Negara, Ghalia Indonesia, Cetakan ke 2, Jakarta 1995, hlm. 57.

${ }^{31}$ Djokosutono, Ibid, hlm. 105.

${ }^{32}$ Ismail Suny, Op. Cit., 1977, hlm. 41; dan Ranggawijaya, Wewenang Menafsirkan UUD, Cita Bakti Akademika, Bandung, 1996, hlm. 52.

${ }^{33}$ Sri Soemantri M, Op. Cit., hlm. 81 dan C.F. Strong, Op. Cit., hlm. 160.
} 
negara Amerika Serikat, dengan istilah populernya adalah “amandemen".${ }^{34}$ Dengan sistem amandemen ini Konstitusi Amerika Serikat (1787) - yang telah diamandemen sebanyak duapuluh tujuh kali - menjadi konstitusi tertua di dunia yang hingga kini masih berlaku.

Dilihat dari segi tingkat kesulitannya, perubahan konstitusi dapat diklasifikasikan menjadi dua bagian yaitu: (1) konstitusi rigid; (2) konstitusi fleksibel. Beberapa konstitusi yang berlaku di negara-negara adalah konstitusi yang rigid. Hanya negara Inggris dan Selandia Baru yang menggunakan konstitusi fleksibel, ${ }^{35}$ karena perubahan konstitusi dilakukan seperti mengubah undang-undang biasa. ${ }^{36}$

\section{Perubahan Konstitusi di Berbagai Negara}

Secara teori cara perubahan konstitusi oleh CF. Strong ${ }^{37}$ dibagi ke dalam 4 kategori, yaitu: (1) melalui parlemen, (2) referendum, (3) persetujuan negara bagian, dan (4) konvensi atau lembaga khusus. Pandangan Strong itu dilakukan oleh beberapa negara. Sebagai contoh, di Republik Rakyat Cina ${ }^{38}$ pengesahan akhir perubahan konstitusi ada di tangan parlemen dengan dukungan suara 2/3 anggota Kongres Rakyat Nasional. Di Perancis ${ }^{39}$ dan Swiss ${ }^{40}$ pengesahan perubahan konstitusi melalui referendum. Sementara pengesahan amandemen konstitusi Amerika Serikat disamping harus didukung oleh $3 / 4$ anggota Kongres juga harus mendapat persetujuan negara-negara bagian. ${ }^{41}$ Cara perubahan yang melalui konvensi dilakukan di negara Argentina. ${ }^{42}$ Dan Cara perubahan yang melalui panitia khusus dilakukan di negara Belanda, ${ }^{43}$ namun pengesahan perubahan konstitusi tetap harus melalui parlemen. Panitia khusus itu dibentuk berdasarkan hasil pemilu.

${ }^{34}$ Pengertian istilah ini mengacu kepada pengertian amandemen versi konstitusi Amerika Serikat, baca: F.E. Cameron, Editor, The Influence of The U.S. Constitution on Pacific Nations, The Asia Foundation, 1988, hlm. 159; dan Sri Soemantri Op. Cit., hlm. 18.

${ }^{35}$ Cheryl Saunders \& Graham Hassall, Editor, Asia-Pacific Constitutional Yearbook 1993, Centre for Comparative Constitutional Studies Universitas of Melbourne, 1995, hlm. 155; dan Eric Barendt, Op. Cit., hlm. 9.

${ }^{36}$ Joeniarto, Selayang Pandang tentang Sumber-sumber Hukum Tata Negara di Indonesia, Liberty, Yogyakarta, 198,1 hlm. 39 "Dengan diperbolehkannya UUD diubah oleh sebuah undang undang yang cara pembuatannya dilakukan dengan cara biasa, maka pada hakekatnya fungsi UUDnya menjadi sama dengan undang-undang biasa".

${ }^{37}$ C.F. Strong, Modern ..., Op. Cit., hlm. 143.

${ }^{38}$ Constitution of The People's Republic of China (1982), Foreign Languages Press, Beijing, Edisi ketiga, 1994, hlm. 45; dan Konstitusi RRC < http://www.urich.edu/ jpjones/confinder/ china.htm>, diakses Febuari 2003.

${ }^{39}$ Prajudi Atmosudirdjo dkk, edt., Konstitusi Perancis, Pasal 89

${ }^{40}$ Prajudi Atmosudirdjo dkk, edt., Konstitusi Swiss, Op. Cit., hlm. 82-84

${ }^{41}$ Prajudi Atmosudirdjo dkk, edt., Konstitusi Amerika Serikat, Op. Cit., hlm. 38; dan Lawrene M. Friedman, American Law : An Introduction, terjemahan Wishnu Basuki, Tatanusa, Jakarta, 2001, hlm. 248.

${ }^{42}$ Prajudi Atmosudiedjo dkk, edt., Konstitusi Argentina, Op. Cit., hlm. 1

${ }^{43}$ Konstitusi Belanda, Adopted on 17 Feb 1983 < http://www.urich.edu/ jpjones/ confinder/nethrlnd.htm>, diakses Febuari 2003. 
Konstitusi Srilangka tahun $2000^{44}$ menggunakan cara gabungan parlemen dan referendum, yaitu untuk amandemen pasal-pasal khusus seperti religi dilakukan melalui referendum, sedang pasal-pasal lainnya melalui parlemen. Cara lainnya adalah seperti yang terjadi di Kerajaan Kuwait. Menurut konstitusi Kuwait, ${ }^{45}$ rajalah satu-satunya organ yang berwenang mengesahkan perubahan konstitusi, sedangkan parlemen hanya diberikan kewenangan dalam proses perumusun ataupun inisitif perubahan konstitusi itu. ${ }^{46}$

Selain ketentuan di atas, beberapa negara juga mengatur usul atau inisiatif atas perubahan konstitusi. Berdasarkan hasil penelitian penulis terhadap 100 konstitusi negara, usul tersebut diajukan oleh berbagai lembaga yang dapat diklasifikasikan menjadi 5 macam, yaitu warga negara, parlemen, pemerintah, mahkamah konstitusi dan negara bagian/propinsi.

Tabel 2

\begin{tabular}{|c|l|l|}
\hline No & Usul Perubahan Konstitusi & \multicolumn{1}{c|}{ Contoh Negara } \\
\hline 1. & Warga Negara & Swis (100rb WN), Muldova (200rb), Parguy (30rb petisi) \\
2. & Parlemen & AS (2/3), Afsel (3/4), RRC (1/5 KR). \\
3. & Eksekutif / Pemerintah & Iran, Perancis, Tunisia \\
4. & Mahkamah Konstitusi & Belarusia \\
5. & Negara Bagian/ Propinsi & AS (2/3). Afsel (6 Daerah), Rusia (1/5 NB) \\
\hline
\end{tabular}

Di samping usul perubahan itu, ada beberapa negara yang mengatur pembatasan atas hal-hal yang tidak boleh diubah dalam konstitusinya. Seperti Konstitusi Perancis mengecualikan bentuk negara republik sebagai obyek perubahan seperti diatur dalam Article 89. ${ }^{47}$ Pembatasan ini juga dikenal dalam Konstitusi Malaysia yang menentukan soal suksesi Raja dan posisi Ketua Adat tidak termasuk obyek amademen yang dilakukan oleh State Legislature. ${ }^{48}$ Pembatasan perubahan konstitusi yang bersifat fundamental itu dapat dilihat dalam konstitusi Timor Timur. ${ }^{49}$

\footnotetext{
${ }^{44}$ Konstitusi Srilangka <http://www.langka. net/contitution/ contens.html>, diakses Febuari 2003.

${ }^{45}$ Konstitusi Kuwait < http://www.uni-wuerzburg.de/law/ Ku00000_html>, diakses Febuari 2003.

${ }^{46}$ Cara demikian tentu dapat dipandang tidak lazim karena melanggar prinsip-prinsip sebuah negara demokrasi.

${ }^{47}$ Konstitusi Perancis, Title XIV Amendment, Article 89 Ayat (5)menyebutkan: “ The republican form of government shall not be subject to amendment”. Konstitusi Perancis Republik ke 5, (ICL Document Status: 25 June 1992) <http:/www.elysee.fr/ang/ instit/txt5814_.htm>, diakses Febuari 2003; dan John Bell, Frenh Constitutional Law, Clarendon Press, Oxford, 1992, hlm. 9

${ }^{48}$ Arikel 9 Ayat (2) menyebutkan: "The provisions affecting succession to the throne and the position of the Ruling Chiefs and similar Malay customary dignitaries may not be amended by the State Legislature", Konstitusi Malaysia <http://www.trybunal. gov.pl/constit/ constitu/constit/malaysia/malays-e.htm>, diakses Febuari 2003.

${ }^{49}$ Konstitusi Timor Timur, Section 156 (Limits on matters of revision). Laws revising the Constitution shall
} 


\section{Perubahan UUD Negara Republik Indonesia Tahun 1945}

Sebagaimana telah dibahas di bagian pendahuluan, terdapat dua cara yang dikenal dalam sistem perubahan undang-undang dasar. Jika dua sistem perubahan tersebut dikaitkan dengan praktek Perubahan I-IV UUD 1945, maka dapat disimpulkan bahwa secara formal Perubahan UUD 1945 mengikuti sistem amandemen, sungguhpun secara material jumlah muatan materi perubahan lebih besar daripada naskah aslinya seperti telah disinggung di atas..$^{50}$ Jauh berbeda dengan amandemen Konstitusi Amerika Serikat yang sejak pembentukannya hingga sekarang baru diamandemen duapuluh tujuh kali ${ }^{51}$ seperti disebut di muka.

Dalam sistem amandemen yang utama adalah berlakunya konstitusi yang telah diubah itu tetap didasarkan pada saat berlakunya konstitusi asli, karena itu, perubahan redaksi dan atau substansi atas beberapa pasal atau ketentuan tersebut dijadikan sebagai suatu adendum atau lampiran dari konstitusi asli. Jadi sedikit banyaknya jumlah ketentuan dalam konstitusi yang diubah bukan merupakan penentu bagi sistem amandemen.

Cara amandemen yang dilakukan atas perubahan UUD 1945 memiliki akibat hukum bahwa keberlakuan ${ }^{52}$ UUD 1945 yang disandarkan pada Dekrit Presiden 5 Juli 1959 masih tetap eksis dan dipertahankan oleh Majelis Permusyawaratan Rakyat hasil Pemilu demokratis tahun 1999, seperti halnya yang dilakukan sebelumnya oleh MPR di masa pemerintahan Presiden Soeharto. ${ }^{53}$ Selain itu, oleh karena yang mengamandemen UUD1945 adalah MPR hasil pemilu tahun 1999 yang demokratis, maka dapat dikatakan bahwa hasil amandemen itu merupakan suatu keputusan hukum yang demokratis. Dengan demikian, amandemen UUD 1945 justru

respect: (a) National independence and the unity of the State; (b) The rights, freedoms and guarantees of citizens; (c) he republican form of government; (d) The separation ofpowers; (e) The independence of the courts; (f) The multi-party system and the right of democratic opposition; $(\mathrm{g})$ The free, universal, direct, secret and regular suffrage of the office holders of the organs of sovereignty, as well as the system of proportional representation; (h) The principle of administrative deconcentration and decentralisation; (i) The National Flag; (J) The date of proclamation of national independence.(Konstitusi Timor Leste 2002)

${ }^{50}$ Lihat Tabel 9 : Jumlah Pasal Perubahan UUD 1945 pada lampiran di belakang

${ }^{51}$ Kronologi amandemen Konstitusi Amerika Serikat tersebut dapat dilihat dalam Richad B. Bernstein dan Jerome Agel, Amanding America..., Op., Cit, hlm. 305-307.

${ }^{52}$ Sebagaimana telah disinggung di atas dalam tulisan ini, Undang Undang Dasar 1945 mulai diberlakukan kembali sejak tanggal 5 Juli 1959 dengan Dekrit Presiden. Undang Undang Dasar 1945 Dekrit Presiden ini yang kemudian mengalami perubahan dengan cara amandemen.

${ }^{53}$ Selama periode pemerintahan Presiden Soeharto (1966-1988), Majelis Permusyawaratan Rakyat selalu mengeluarkan suatu ketetapan yang isinya antara lain "tetap mempertahankan UUD 1945 dan tidak akan mengubahnya". Baca Harun Alrasid, Penetapan UUD dan Perubahan UUD dalam Teori dan Praktek, Pidato Purna Bakti Gusu Besar Tetap Fakultas Hukum Universitas Indonesia, Jakarta, 20 Juli 1996, hlm. 24 
memperkuat eksistensi keabsahan UUD 1945, ${ }^{54}$ atau dapat dikatakan bahwa secara tidak langsung atau diam-diam MPR telah mengukuhkan keabsahanUUD 1945 atas dasar Dekrit Presiden itu..$^{55}$ Jadi pertanyaan apakah UUD 1945 (baca: “versi” Dekrit Presiden 1959) perlu harus disahkan lebih dahulu oleh Majelis Permusyawaratan Rakyat, sekarang bukan lagi merupakan persoalan yang penting, apalagi ketentuan asli Ayat (2) Aturan Tambahan UUD 1945 yang mewajibkan MPR untuk menetapkan UUD setelah enam bulan majelis terbentuk, ${ }^{56}$ sudah tidak tercantum lagi dalam Perubahan Undang-Undang Dasar $1945 .{ }^{57}$ Selian itu perubahan atas UUD tersebut dilakukan oleh MPR hasil Pemilihan Umum tahun 1999 yang berjalan secara demokratis.

\section{Penutup}

Setelah dilakukan pembahasan hasil penelitian sebagaimana diuraikan di atas, maka sampailah kini pada kesimpulan. Seluruh uraian di atas menunjukan beberapa hal yang dapat peneliti simpulkan sebagai berikut:

Pertama, cara amandemen pertama sampai dengan keempat UUD 1945 secara teori tidak menyimpang dari prinsip-prinsip umum perubahan konstitusi dan prinsipprinsip negara demokrasi, apalagi lembaga yang melakukan perubahan tersebut adalah MPR hasil Pemilu tahun 1999 yang diakui publik berlangsung demokrtis.

Kedua, berdasarkan penelitian pada beberapa konstitusi negara ditemukan beberapa ketentuan cara perubahan konstitusi, yaitu: (1) Usul atau inisiatif perubahan konstitusi; (2) Pembahasan usul inisiatif itu untuk diterima atau ditolak menjadi agenda resmi perubahan; (3) Pembahasan terhadap perubahan yang diusulkan tersebut; (4)

\footnotetext{
${ }^{54}$ Bandingkan pandangan Bagir Manan dalam "Indonesia Lakukan Lompatan Besar, Hasil ST MPR 2002 Sah", Suara Karya, Jakarta, 12 Agustus 2002.

${ }^{55}$ Bandingkan dengan Pandangan Akhir Fraksi Perserikatan Daulatul Ummah (PDU), yang menyatakan antara lain: "Undang Undang Dasar 1945 yang berdasarkan Dekrit Presiden 5 Juli 1959 telah dijiwai dan disatukan sebagai satu kesatuan dengan Piagam Jakarta yang notabene didukung dan diterima sepenuhnya oleh Dewan Perwakilan Rakyat hasil Pemilu 1955 dan oleh seluruh rakyat Indonesia, inilah [UUD 1945-pen] yang secara sah dan konstitusional diberlakukan kembali sejak tanggal 5 Juli 1959 sampai detik ini [9 Agustus 2002-pen]. Undang Undang Dasar 1945 ini pula yang kini [2002-pen] tengah kita bahas perubahan-perubahannya”. Lihat: Sekretariat Jenderal MPR RI, Buku Keempat: Risalah Rapat Paripurna MPR RI Ke-1 s.d. 7, Tanggal 1 s.d. 11 Agustus 2002, Masa Sidang Tabunan MPR RI, Tahun 2002, hlm. 527-528.

${ }^{56}$ Naskah asli UUD 1945 Ayat (2) Aturan Tambahan berbunyi: "Dalam enam bulan sesudah Majelis Permusyawaratan Rakyat dibentuk, Majelis itu bersidang untuk menetapkan Undang Undang Dasar".

${ }^{57}$ Kententuan Ayat 2 ini telah diamandemen menjadi Pasal II Aturan Tambahan, yang berbunyi: "Dengan ditetapkannya perubahan Undang-Undang Dasar ini, Undang-Undang Dasar Negara Republik Indonesia Tabun 1945 terdiri atas Pembukaan dan pasal-pasal'
} 
Pengesahan dan/atau (5) Pengumuman resmi pemberlakuan perubahan konstitusi; (6) Ketentuan korum sidang; (7) Ketentuan kewenangan lembaga pembentuk perubahan konstitusi; (8) Pembatasan materi konstitusi yang tidak boleh diubah; (9) Pembatasan materi konstitusi yang baru boleh diubah dengan persyaratan tertentu atau khusus (referendum). Ketentuan-ketentuan angka 1 sampai dengan 5 di atas merupakan tahapan dalam prosedur perubahan konstitusi. Sedangkan angka 6 sampai 9 merupakan ketentuan lain sebagai bagian dari cara perubahan konstitusi.

Ketiga, perubahan UUD 1945 pertama, kedua, ketiga dan keempat yang mencakup 75 "pasal" itu dilakukan dengan mengikuti bentuk adendum atau sistem amandemen Konstitusi Amerika Serikat, yakni bagian yang diamandemen merupakan atau menjadi bagian dari konstitusi UUD 1945. Dengan demikian, status hukum berlakunya UUD 1945 masih digantungkan atau didasarkan pada Dekrit Presiden 5 Juli 1959. Artinya di sini bahwa alasan-alasan yang melatar-belakangi kembalinya UUD 1945 seperti “jiwa piagam jakarta”, yang menjadi salah satu dasar pertimbangan Dekrit Presiden tersebut sehingga dapat diterima oleh rakyat Indonesia, masih tetap eksis, dan bahkan posisinya menjadi semakin kuat karena amandemen Undang-Undang Dasar tersebut dilakukan oleh MPR hasil pemilu (tahun 1999) yang demokratis. Oleh karena itu, keabsahan UUD 1945 bukan merupakan persoalan lagi. Sesuai asas umum, suatu ketentuan hukum baik itu berupa norma dasar (baca: undang-undang dasar), ataupun aturan pelaksana yang lahir secara ektra konstitusional, sepanjang dapat diterima oleh masyarakat atau lembaga formal kenegaraan maka ia memiliki nilai yuridis. Ini sejalan dengan teori konvensi atau revolusi atau secara singkat dapat dikatakan bahwa pada hakekatnya UUD 1945 dan Perubahan-perubahannya itu merupakan “UUD Dekrit Presiden 5 Juli 1959 dan Perubahan-perubahannya".

\section{Daftar Pustaka}

Alrasid, Harun, "Ketetapan MPR Suatu Pemikiran Kembali", dalam Pekan Ilmiah, Lembaga Penelitian Hukum Fakultas Hukum Universitas Sriwijaya, Palembang, 1976

- Penetapan UUD dan Perubahan UUD dalam Teori dan Praktek, Pidato Purna Bakti Guru Besar Tetap Fakultas Hukum Universitas Indonesia, Jakarta, 20 Juli 1996.

Bernstein, Richard B., with Jerome Agel, Amending America, Times Books Random House, First Edition, New York, 1993. 
Cameron, F.E., Editor, The Influence of The U.S. Constitution on Pacific Nations, The Asia Foundation, 1988.

Corpus Juris Scundum, Constitutional Law, Volume 16, Brooklyn, N.Y. The American Law Book, tanpa tahun

Djokosutono, Hukum Tata Negara, Ghalia Indonesia, cetakan kedua, Jakarta, 1985.

Friedman, Lawrene M., American Law : An Introduction, terjemahan Wishnu Basuki, Tatanusa, Jakarta, 2001.

Hatta, Mohammad , Memoir Mohammad Hatta, Tintamas, Jakarta 1982

Ismaun, Pancasila Dasar Filsafat Negara Republik Indonesia, Carya Remaja, edisi IV, Bandung, 1977

Jenning, Ivor , The Laws and the Constitution, University of London, 1960

Joeniarto, Selayang Pandang tentang Sumber-sumber Hukum Tata Negara di Indonesia, Liberty, Yogyakarta, 1981.

Konstitusi Belanda, Adopted on 17 Feb 1983 <http://www.urich.edu/ jpjones/ confinder/nethrlnd.htm>, diakses Febuari 2003.

Konstitusi Kuwait <http:/ / www.uni-wuerzburg.de/law/ Ku00000_html>, diakses Febuari 2003.

Konstitusi Malaysia <http://www.trybunal.gov.pl/constit/ constitu/constit/ malaysia / malays-e.htm>, diakses Febuari 2003.

Konstitusi Perancis, Title XIV Amendment, Article 89 Ayat (5)menyebutkan: “ The republican form of government shall not be subject to amendment". Konstitusi Perancis Republik ke 5, (ICL Document Status: 25 June 1992) <http:/ www.elysee.fr/ang/ instit/txt5814_.htm>, diakses Febuari 2003; dan John Bell, Frenh Constitutional Law, Clarendon Press, Oxford, 1992

Konstitusi RRC < http:/ / www.urich.edu/ jpjones/confinder/ china.htm>, diakses Febuari 2003.

Konstitusi Srilangka <http:/ / www.langka.net/contitution/ contens.html>, diakses Febuari 2003.

Konstitusi Timor Timur, Section 156 (Limits on matters of revision) Laws revising the Constitution shall respect: Konstitusi Timor Leste 2002.

Mahendra, Yusril Ihza, Dinamika Tata Negara Indonesia, Gema Insani Press, Jakarta, 1996. , Modernisme dan Fundamentalisme dalam Politik Islam, Paramadina, Jakarta, 1999.

, "Indonesia Lakukan Lompatan Besar, Hasil ST MPR 2002 Sah", Suara Karya, Jakarta, 12 Agustus 2002.

Moore,Russell F. , Basic Comparative Government and Modern Constitution, Iowa, 1957

Mueller, Dennis C., Constitutional Democracy, Oxford University Press, 1996

Oltmans, Willem, Chaos in Indonesia, terjemahan Wahjoedi Marjono, Surya Multi Grafika, Cet. 1, Jakarta, 2001. 
Ranggawijaya, Wewenang Menafsirkan UUD, Cita Bakti Akademika, Bandung, 1996

Richad, B. Bernstein dan Jerome Agel, Amanding America, Times Books, New York, 1993.

Rousseau, Jean-Jacques, The Social Contrat and Discourses. Terjemahan dalam bahasa Inggris oleh G.D.H. Cole, J.M.Dent \& Sons Ltd, Reprinted, London, 1991

Saunders, Cheryl \& Graham Hassall, Editor, Asia-Pacific Constitutional Yearbook 1993.

Sekretariat Jenderal MPR RI, Buku Keempat, Risalah Rapat Paripurna MPR RI Ke-1 s.d. 7, Tanggal 1 s.d. 11 Agustus 2002, Masa Sidang Tahunan MPR RI, Tahun 2002.

Sekretariat Negara Republik Indonesia, Risalah Sidang Badan Penyelidik UsahaUsaha Persiapan Kemerdekaan Indonesia (BPUPKI) Panitia Persipan Kemerdekaan Indonesia (PPKI) 28 Mei 1945 - 22 Agustus 1945, Sekretariat Negara Republik Indonesia, Jakarta, 1995.

Soekanto, Soerjono dan Sri Mamudji, Penelitian Hukum Normatif, In-Hilco, Jakarta, 1990.

Soemantri, Sri, Prosedur dan Sistem Perubahan Konstitusi, cetakan pertama tahun 1978.

Strong, C.F. Modern Political Constitutions: An Introduction to the Comperative Study of ther History and Existing Form, Sudgwick \& Jackson, London 1973.

Suny, Ismail . Pergeseran Kekuasaan Eksekutif, CV Calindra, Cet.2, Jakarta 1965.

Yamin, Muhammad, Naskah Persiapan UUD 1945, Jilid I, Prapantja, Jakarta.

Constitution of The People's Republic of China (1982), Foreign Languages Press, Beijing, Edisi ketiga, 1994.

Majalah Hukum dan Masyarakat, Tahun III No. 2 Mei 1958 